\title{
Wetter is Better: Rewetting of Minerotrophic Peatlands Increases Plant Production and Moves Them Towards Carbon Sinks in a Dry Year
}

\author{
Sarah Schwieger, ${ }^{1 *} \odot$ Juergen Kreyling, ${ }^{1} \odot$ John Couwenberg, ${ }^{2}$ \\ Marko Smiljanić, ${ }^{3} \odot$ Robert Weigel, ${ }^{4} \odot$ Martin Wilmking, ${ }^{3} \odot$ and \\ Gesche Blume-Werry ${ }^{1} \odot$
}

\begin{abstract}
${ }^{1}$ Experimental Plant Ecology, Institute of Botany and Landscape Ecology, Greifswald University, 17487 Greifswald, Germany; ${ }^{2}$ Peatland Studies and Palaeoecology, Institute of Botany and Landscape Ecology, Greifswald University, 17487 Greifswald, Germany; ${ }^{3}$ Landscape Ecology and Ecosystem Dynamics, Institute of Botany and Landscape Ecology, Greifswald University, 17487 Greifswald, Germany; ${ }^{4}$ Plant Ecology, Albrecht-von-Haller-Institute for Plant Sciences, University of Goettingen, 37073 Göttingen, Germany
\end{abstract}

\begin{abstract}
Peatlands are effective carbon sinks as more biomass is produced than decomposed under the prevalent anoxic conditions. Draining peatlands coupled with warming releases stored carbon, and subsequent rewetting may or may not restore the original carbon sink. Yet, patterns of plant production and decomposition in rewetted peatlands and how they compare to drained conditions remain largely unexplored. Here, we measured annual above- and belowground biomass production and decomposition in three different drained and rewetted peatland types: alder forest, percolation fen and coastal fen during an exceptionally dry year. We also used standard plant material to
\end{abstract}

Received 8 June 2020; accepted 21 September 2020; published online 26 October 2020

Electronic supplementary material: The online version of this article (https://doi.org/10.1007/s10021-020-00570-z) contains supplementary material, which is available to authorized users.

Authors Contributions GBW, JK and SS conceived and designed the study; GBW, MS and SS performed the research; JK, MS and SS analysed the data; GBW, JK, MW, RW, JC and SS contributed to the interpretation of the results. SS led the writing of the manuscript. All authors contributed critically to the drafts and gave final approval for publication.

*Corresponding author; e-mail: sarah.schwieger@uni-greifswald.de compare decomposition between the sites, regardless of the decomposability of the local plant material. Rewetted sites showed higher root and shoot production in the percolation fen and higher root production in the coastal fen, but similar root and leaf production in the alder forest. Decomposition rates were generally similar in drained and rewetted sites, only in the percolation fen and alder forest did aboveground litter decompose faster in the drained sites. The rewetted percolation fen and the two coastal sites had the highest projected potential for organic matter accumulation. Roots accounted for $23-66 \%$ of total biomass production, and belowground biomass, rather than aboveground biomass, was particularly important for organic matter accumulation in the coastal fens. This highlights the significance of roots as main peat-forming element in these graminoid-dominated fen peatlands and their crucial role in carbon cycling, and shows that high biomass production supported the peatlands' function as carbon sink even during a dry year.

Key words: decomposition; fen; fine root production; in-growth core; litter bag; organic matter accumulation; peatland; wetland. 


\section{HighLIGHTS}

- Rewetting increased biomass production and supported the peatlands C sink functions

- High biomass production compensated for decomposition losses even during a dry year

- Root biomass was important for organic matter accumulation in graminoid fens

\section{INTRODUCTION}

Peatlands represent the most space efficient carbon (C) stores among terrestrial ecosystems. Although covering only about $3 \%$ of the terrestrial surface, their total C pool exceeds that of the world's forests and is equivalent to about $60 \%$ of the $\mathrm{C}$ in the atmosphere (Joosten and Couwenberg 2008; Joosten and others 2016). In the past 200 years, human activities have reduced the area of pristine, peat accumulating peatlands by about $50 \%$ in Europe (Joosten and Clarke 2002; Tanneberger and others 2017). Drainage, for example, for agriculture and forestry, has led to aeration of the peat and its subsequent decomposition, effectively turning peatlands into $\mathrm{C}$ sources, jeopardizing their climate change mitigation function (Joosten 2009; Joosten and others 2016; Leifeld and others 2019). To counteract the negative effects of peatland drainage (for example, carbon loss, eutrophication, surface subsidence, loss of water retention and loss of habitat), drained sites are rewetted worldwide. However, many site characteristics have fundamentally and irreversibly changed during drainage (for example, bulk density, nutrient content, species pool) and, as a result, rewetting often does not lead to the restoration of the original ecosystem functions (Lamers and others 2015; Bonn and British Ecological Society 2016). Rewetting may result in recovery of the $\mathrm{C}$ sequestration function (Tuittila and others 1999; Graf and Rochefort 2015; Bérubé and Rochefort 2018; Günther and others 2015). This process is usually driven by low rates of decomposition, caused by water saturation leading to anoxia, which inhibit the activity of aerobic decomposers (that is, bacteria and fungi) (Denny 1993; Freeman and others 2001; Moore and others 2007). The balance between production and decomposition of organic matter (OM) is thus crucial for evaluating a rewetted peatland's potential to store $\mathrm{C}$ again. In addition, this balance can be considerably influenced by extreme weather and climate events, as we experienced them in the hot and dry year 2018 (Schuldt and others 2020) and that are expected to occur more often in the future (IPCC 2013; Rahmstorf and Coumou 2011; Stott 2016). Increasingly warm and dry conditions introduce oxygen into these systems, stimulating microbial growth and raising the breakdown of OM and the release of C (Fenner and Freeman 2011). Evidence exists that also peatlands that often experience short-term droughts (that is, over summer) continue to preserve $\mathrm{C}$ depending on their vegetation (Wang and others 2015). The balance between production and decomposition depends not only on abiotic factors, such as water table depth (Wieder and others 2006) and soil temperature (Moore and others 2007), but also heavily on the vegetation present. For example, litter quality alone explains about $65 \%$ of litter decomposition rates (Thormann and Bayley 1997; Zhang and others 2008; Parton and others 2007; Djukic and others 2018), and even within a single plant species, litter decomposability can differ with roots often decomposing slower than shoots (Zhang and others 2008; Freschet and others 2013). Thus, root production is potentially more important for peat formation than aboveground production. In fact, in the extensive river valley peatlands of lowland Europe, the peat is formed primarily by roots and rhizomes and not by mosses (Carex-peat) (Succow and Joosten 2001; Michaelis and others 2020). Nevertheless, roots and their potential contribution to peat accumulation remain understudied.

Fine roots $(<2 \mathrm{~mm}$ in diameter, Pregitzer and others 2002) are short-lived roots whose main function is the uptake of nutrients and water from the soil (Guo and others 2008). Fine root production accounts for up to $22 \%$ of the worldwide annual net primary production (McCormack and others 2015) and controls, besides nutrient and water uptake, a large flux of $\mathrm{C}$ from plants into the soil in form of root exudates and fine root turnover (McCormack and others 2013; Pendall and others 2004). Despite the major role of belowground litter as a driver of ecosystem OM dynamics (Freschet and others 2013), decomposition studies mainly focus on leaf litter (Aerts 1997; Meentemeyer and Berg 1986; Zhang and others 2008) or use standard material (Domisch and others 2006; Laiho and others 2004; Minkkinen and others 1999; Lieffers 1988). However, such studies only describe the effects of environmental factors on decomposition (that is, decomposition potential), without the effect of litter quality of the actual present vegetation (Laiho 2006; Hartmann 1999). The use of local plant material, including roots of different soil depths, along with standard material potentially 
allows to disentangle the effect of abiotic factors and the litter quality for a given site.

Here, we studied three characteristic peatlands of the North European Plain (that is, lowlands affected by Pleistocene glaciation): an alder forest, a percolation fen and a coastal fen, each in a drained and a rewetted state. All these peatlands are fens (that is, minerotrophic peatlands that receive surface or ground water) and their peats are comprised of roots. The objective of this study was to measure above- and belowground biomass production and decomposition in both drained and rewetted sites in these three different fen types, in order to compare their peat-forming potential after rewetting. Compared to the long-term average values of the last climate reference period, the year 2018 was a very warm and dry year. So far, we lack knowledge of the effects that these drought events will have on plant production and decomposition and thus the $\mathrm{C}$-storage function of rewetted fen peatlands.

We expected that rewetted sites are characterized by wetter soil conditions compared with their drained counterparts even in an exceptionally dry year. Thus, we hypothesized that rewetted sites have (i) higher biomass production due to reduced drought stress, (ii) lower decomposition rates due to longer periods of water saturation in the soil inhibiting aerobic microbial activity, and finally that (iii) rewetting increases the potential for accumulation of OM, even in an exceptionally dry year.

\section{Materials AND Methods}

\section{Study Area}

All study sites were located in the German federal state of Mecklenburg-Western Pomerania in the North European Plain of north-eastern Germany with an average elevation of less than $6 \mathrm{~m}$ a.s.l. (Table 1). The study region has a maritime climate with a mean annual temperature of $8.8^{\circ} \mathrm{C}$ and mean annual precipitation of $565 \mathrm{~mm}$. January is the coldest month with a mean temperature of $0.6^{\circ} \mathrm{C}$ and a mean precipitation of $40 \mathrm{~mm}$, whereas July is warmest with a mean temperature of $16.7^{\circ} \mathrm{C}$ and a mean precipitation of $62 \mathrm{~mm}$ (meteorological data provided by Germany's National Meteorological Service from 1981 to 2010). The years from 2015 to 2018 were, compared to the average climate over the last 30 years, dry and warm years (World Meteorological Organization (WMO)

Table 1. General Description of the Study Sites

\begin{tabular}{|c|c|c|c|c|c|c|}
\hline & \multicolumn{6}{|l|}{ Peatlands } \\
\hline & \multicolumn{2}{|l|}{ Alder forest } & \multicolumn{2}{|c|}{ Percolation fen } & \multicolumn{2}{|l|}{ Coastal fen } \\
\hline & Drained & Rewetted & Drained & Rewetted & Drained & Rewetted \\
\hline \multirow[t]{2}{*}{ Geographic coordinates } & E $12^{\circ} 32^{\prime} 11^{\prime \prime}$ & E $12^{\circ} 29^{\prime} 04^{\prime \prime}$ & E $12^{\circ} 37^{\prime} 43^{\prime \prime}$ & E $12^{\circ} 44^{\prime} 22^{\prime \prime}$ & E $13^{\circ} 23^{\prime} 09^{\prime \prime}$ & $\mathrm{E} 13^{\circ} 23^{\prime} 21^{\prime \prime}$ \\
\hline & N $54^{\circ} 08^{\prime} 06^{\prime \prime}$ & N $54^{\circ} 07^{\prime} 37^{\prime \prime}$ & $\mathrm{N} 54^{\circ} 07^{\prime} 55^{\prime \prime}$ & N $54^{\circ} 06^{\prime} 04^{\prime \prime}$ & $\mathrm{N} 54^{\circ} 09^{\prime} 28^{\prime \prime}$ & N $54^{\circ} 09^{\prime} 27^{\prime \prime}$ \\
\hline $\begin{array}{l}\text { Distance drained/ } \\
\text { rewetted }(\mathrm{km})\end{array}$ & 3.5 & & 8 & & 0.2 & \\
\hline Year of drainage & $\sim 1900$ & $\sim 1900$ & 1970 & $\sim 1750$ and 1970 & 1850 & 1850 \\
\hline Year of rewetting & - & $2003 / 2004$ & - & 1997 & - & 1993 \\
\hline Peat depths (cm) & 60 & 200 & 400 & 600 & 70 & 30 \\
\hline $\mathrm{pH}$ & 4.3 & 5.1 & 5.1 & 5.4 & 4.0 & 4.6 \\
\hline $\begin{array}{l}\text { Dry bulk density } \\
\qquad\left(\mathrm{g} \mathrm{cm}^{-3}\right)^{\mathrm{a}}\end{array}$ & 0.55 & 0.16 & 0.28 & 0.28 & 0.63 & 0.57 \\
\hline $\mathrm{NH}_{4}-\mathrm{N}\left(\mathrm{mg} \mathrm{kg}^{-1}\right)^{\mathrm{b}}$ & $23.02 \pm 21$ & $89.37 \pm 70$ & $39.56 \pm 5$ & $44.94 \pm 18$ & $11.07 \pm 3$ & $19.62 \pm 7$ \\
\hline $\mathrm{NO}_{3}-\mathrm{N}\left(\mathrm{mg} \mathrm{kg}^{-1}\right)^{\mathrm{b}}$ & $11.42 \pm 4$ & $13.27 \pm 11$ & $9.84 \pm 8$ & $6.36 \pm 5$ & $0.52 \pm 0$ & $0.50 \pm 0$ \\
\hline $\mathrm{P}\left(\mathrm{mg} \mathrm{kg}^{-1}\right)^{\mathrm{b}}$ & $632 \pm 261$ & $2072 \pm 201$ & $1102 \pm 373$ & $1059 \pm 131$ & $655 \pm 100$ & $757 \pm 89$ \\
\hline $\mathrm{K}\left(\mathrm{mg} \mathrm{kg}^{-1}\right)^{\mathrm{b}}$ & $574 \pm 15$ & $487 \pm 224$ & $241 \pm 136$ & $511 \pm 91$ & $3014 \pm 24$ & $2285 \pm 333$ \\
\hline $\operatorname{Mg}\left(\mathrm{mg} \mathrm{kg}^{-1}\right)^{\mathrm{b}}$ & $731 \pm 1058$ & $1058 \pm 40$ & $790 \pm 66$ & $2031 \pm 879$ & $3162 \pm 526$ & $2531 \pm 259$ \\
\hline
\end{tabular}


2018), with annual temperatures of $10-11^{\circ} \mathrm{C}$ and mean annual precipitation $\leq 450 \mathrm{~mm}$ (Germany's National Meteorological Service).

\section{Experimental Set-Up}

We studied three different minerotrophic peatland types ( $=$ fens) with peats mainly consisting of roots: alder forest, percolation fen, and coastal fen (Table 1). Each peatland type included a drained and a subsequently rewetted site. Within each study site, a representative study area with a size of $10 \mathrm{~m} \times 35 \mathrm{~m}$ was set-up. The study area was fenced to exclude pasture and wild animals and a central boardwalk has been built in longitudinal direction to avoid ground disturbance (Jurasinski and others 2020). Five plots $(3 \times 3 \mathrm{~m})$ were evenly distributed approximately $10 \mathrm{~m}$ from each other inside the study area with three plots located at the north side and two plots located at the south side of the boardwalk. Sites shared the same macroclimate, but differed in their microclimatic conditions (Table S1). Rewetted sites generally showed moister conditions with clearly higher water tables compared to the drained sites (Figure 1). However, during the warm and dry year 2018, water tables dropped down to $-80 \mathrm{~cm}$ even in the rewetted sites (Figure 1, Table S1). Still, rewetted sites experienced water saturation close to or exceeding soil surface for considerably longer periods than their drained counterparts did.

Our study compared six sites with replicates within each site but not for each fen type. Appro- priate, additional replicates at the fen type level are not readily available in this region, in particular for the rewetted states. Furthermore, monitoring and sampling them would have surpassed our resources. Importantly, our study sites were selected to be representative of each respective fen type in the broader region in terms of basic site characteristics (Table S2). Furthermore, geostatistical analyses in fen peatlands in the region showed that spatial auto-correlation is almost absent (Koch and others 2014, 2016). Therefore, spatial replicates in the field can be seen as independent and their variation as being representative for the respective vegetation type. Based on these aspects, we describe our statistical results as comparisons between the six study sites, but see good reasons for them being representative for the respective fen types.

\section{Study Sites}

Alder forests are deciduous fen woodlands, dominated by Alnus glutinosa (L.) GAERTN. with a poorly developed shrub layer, but a species-rich herbaceous layer with plants that prefer base-rich soil conditions, often moving groundwater and a rather constant water table (Joosten and others 2017). Alnus glutinosa can be found on peatland sites and be peat forming due to its adaptions to water saturated conditions and its tolerance to stagnant waters (McVean 1956; Succow and Joosten 2001; Barthelmes and others 2010). The two study sites are stands of the same forest, a former natural alder swamp, that was drained for wood pasture in the
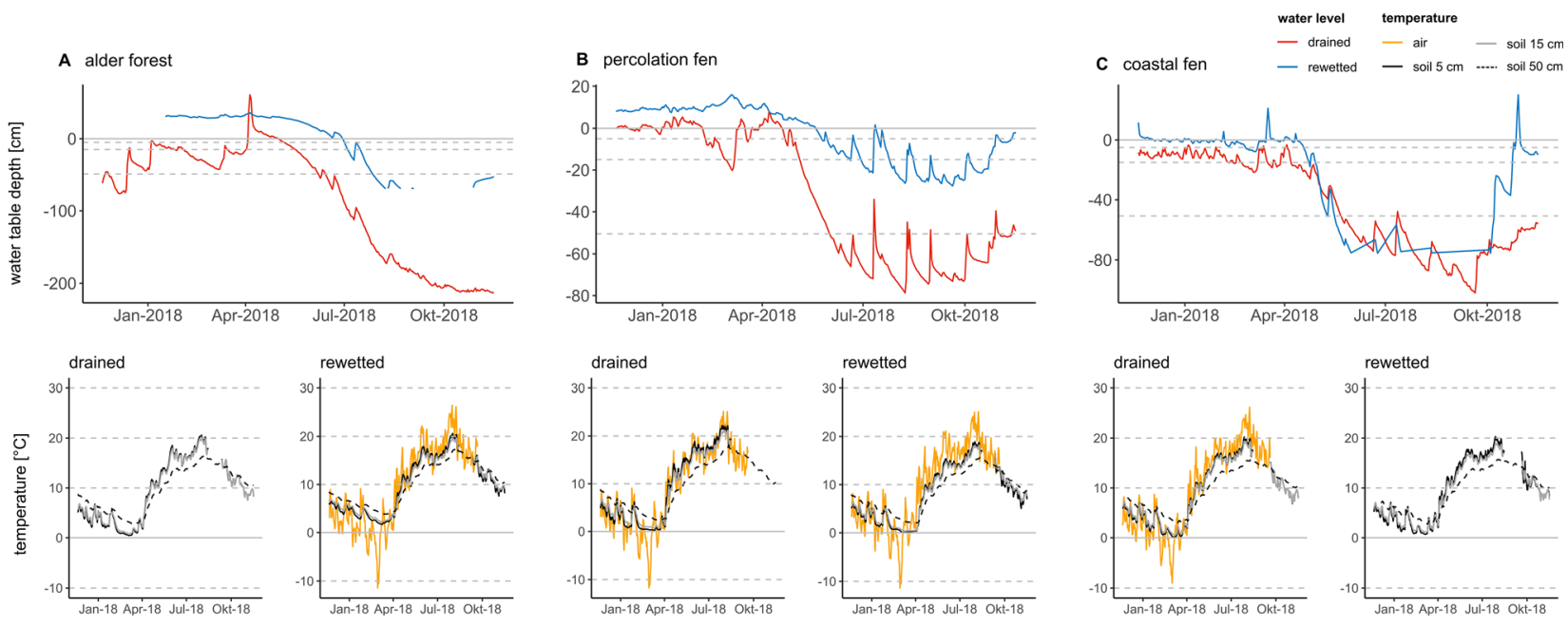

Figure 1. Groundwater table and weather data obtained from the local weather stations for the fen types alder forest (A), percolation fen $(\mathbf{B})$ and coastal fen $(\mathbf{C})$. Displayed are water table depths $(\mathrm{cm})$ for the drained (red line) and rewetted $($ blue line) sites of each fen type, as well as the air temperature (orange line), and soil temperature in two depths of $5 \mathrm{~cm}$ (black line), $15 \mathrm{~cm}$ (grey line) and $50 \mathrm{~cm}$ (dashed black lines). Between August 23 and October 27 of 2018 the water table in in the alder forest $(\mathbf{A})$ fell below $-70 \mathrm{~cm}$, exceeding the depth of the groundwater tube at this site. 
end of the eighteenth century and subsequently used as production forests; one site was rewetted in 2003/2004 (Jurasinski and others 2020). The tree layer of the drained alder stand is characterized by A. glutinosa with a few individuals of Fraxinus excelsior L., while the understory is dominated by Urtica dioica L. (c. 45\% cover) and Rubus idaeus L. (c. $40 \%$ cover). The understory of the rewetted alder stand is dominated by Carex riparia CuRTIS (c. 70\% cover) with occasionally occurring Glyceria fluitans (L.) R.BR. (c. 30\% cover) and Solanum dulcamara L. (c. $20 \%$ cover). The two sites lie within the same basin and are about $3 \mathrm{~km}$ apart.

The drained and rewetted lowland percolation fens were, respectively, located in the hydrologically connected lower Recknitz and Trebel valley, about $8 \mathrm{~km}$ apart. In their natural state, percolation fens are characterised by high, stable water tables and a substantial water flux that percolates the whole peat body. Percolation fens are bound to landscapes where water supply is large and evenly distributed over the year and are found in river valleys (Joosten and others 2017). The drained percolation fen site is used as intensive grassland (Jurasinski and others 2020); its vegetation is mainly comprised of Holcus lanatus L. (c. $80 \%$ cover), Ranunculus repens L. (c. 60\% cover), Poa trivialis L. (c. $30 \%$ cover) and Deschampsia cespitosa (L.) P.Beauv. (c. 15\% cover). The rewetted percolation fen (rewetted in 1997) is protected for nature conservation and not managed. The vegetation is dominated by a vegetation with Carex acutiformis EнRн. (c. $1 \mathrm{~m}$ height, $80 \%$ cover), Phalaris arundinacea L. (c. $40 \%$ cover) and scattered individuals of Epilobium hirsutum L., Equisetum fluviatile L. EMEND. EHRH. and Lythrum salicaria L.

Originally, the coastal fens of the study region were occasionally flooded with brackish sea water during storm surges. The accumulation of groundwater and the infiltration of brackish water contributed to their formation (Kirchner 1971). The vegetation of the drained (and diked) coastal site is dominated by Elymus repens (L.) Gould (c. 80\% cover) and (less abundant) by Juncus effusus L. (c. $35 \%$ cover), Deschampsia cespitosa (L.) P.Beauv. (c. $20 \%$ cover), Dactylis glomerata L. (c. 20\% cover) and Holcus lanatus L. (c. 10\% cover). The vegetation of the rewetted site (rewetted by dike removal in 1993) is comprised of Agrostis stolonifera L. (c. $90 \%$ cover), Festuca rubra agg. L. (c. 20\% cover) and occasionally Juncus gerardii Loisel. The drained and rewetted site are about $200 \mathrm{~m}$ apart and both sites are used for cattle grazing.

\section{Plant Biomass Production}

\section{Aboveground}

Aboveground biomass production of herbaceous plants and shrubs was measured by harvesting biomass on five square areas of $0.33 \times 0.33 \mathrm{~m}$ within each of the five $3 \times 3 \mathrm{~m}$ plots (in total $5.5 \mathrm{~m}^{2}$ per plot) at each of the respective sites. Harvest took place in the beginning and end of July, coinciding with mowing in the coastal and drained percolation fens and thus mimicking the current use at these sites to promote the same vegetation composition as outside the fence. In addition, we harvested in the beginning of October 2018 to prevent underestimation of the biomass production because of loss of senescent leaves. Annual leaf production of the trees was measured with litter traps ( $n=5$ per site) that were emptied at least every 1 to 2 weeks from mid-October until the end of November 2018.

Accumulation of tree stem biomass was estimated using point dendrometer data for annual radial increment values from three trees per site. These radial increments (tree ring width) were then converted to basal area increment and ultimately to volume increment using a form factor of 0.5 (that is, ratio of the volume of the stem to the volume of the cylinder) (Pretzsch 2009). Volume was converted to biomass using a wood density of $495 \mathrm{~kg} \mathrm{~m}^{-3}$ (Meier 2015).

\section{Belowground}

We measured belowground biomass production in two soil depths $(0-5 \mathrm{~cm}$ and $15-20 \mathrm{~cm})$ with ingrowth cores. For this purpose, a plastic mesh with a mesh size of $2 \mathrm{~mm}$ (\#7 Mesh Plastic Canvas Artist Sheet, size $34.6 \mathrm{~cm} \times 57.5 \mathrm{~cm}$ from Darice Inc., Strongsville, OH, USA) was shaped into a tube of $5 \mathrm{~cm}$ diameter and a length of c. $72 \mathrm{~cm}$ and the lower end was closed off with a plastic plug. Ingrowth cores were filled with autochthonous peat, free of living roots, taken in the field from each of the two respective depths (at original bulk densities). In each of five plots per site, we installed three in-growth cores at an angle of $45^{\circ}$, resulting a total of 90 in-growth cores. The cores were installed between 20 November and 1 December 2017 and retrieved after 1 year between 14 and 16 of November 2018. After retrieval of the in-growth cores, protruding roots were cut at the mesh and roots were subsequently washed out and dried at $70^{\circ} \mathrm{C}$ for at least $48 \mathrm{~h}$ in a drying oven before weighing. We also measured root production in $40-45 \mathrm{~cm}$ depth, but excluded the results, because 
we were not able to compare with decomposition data in this depth, as root material for litter bags was lacking at this depth at some sites.

\section{Decomposition}

\section{Belowground Material}

Autochthonous root material was collected at each site between June and October 2017 from 0 to $10 \mathrm{~cm}$ and 10 to $20 \mathrm{~cm}$ depth; roots sampled at different depths were kept separated in processing and incubation. Roots were stored at $+4^{\circ} \mathrm{C}$ until processing. Following the rationale of Hobbie and others (2010), we used fresh roots for our decomposition analysis. The collected roots were washed clean from peat and 'air dried' at $35^{\circ} \mathrm{C}$ in a drying oven. A subsample from each site was dried at $70^{\circ} \mathrm{C}$ for $48 \mathrm{~h}$ to determine dry weight. Root material corresponding to $0.5 \mathrm{~g}$ dry weight was placed into nylon mesh bags (size $5 \mathrm{~cm} \times 6 \mathrm{~cm}$, mesh size $0.14 \mathrm{~mm}$ ), which were heat-sealed. To keep the litter bags in place, they were attached to a nylon mesh (tulle with a mesh size of $3 \mathrm{~mm}, 20 \mathrm{~g} \mathrm{~m}^{-2}$ ) that was placed between two sheets of a highdensity polyethylene woven mesh (TopZeven, The Netherlands, mesh size $10 \times 10 \mathrm{~mm}, 420 \mathrm{~g} \mathrm{~m}^{-2}$, final frame size $55 \mathrm{~cm} \times 24 \mathrm{~cm}$ ). The 'litter frames' were installed vertically into the soil by hammering metal plates into the ground, then prying them apart to create a slot large and deep enough for the frames to be slid into and be completely buried in the ground, and then removing the metal plates. The created gaps closed within minutes by lateral pressure of the peat. In each of five plots per site, three 'litter frames' were installed and retrieved at the same time as the in-growth cores (six sites $x$ five plots $\times$ two depths $\times$ three replicates total). After retrieval, the root bags were air dried, cleaned and in-grown roots were removed. Finally, root remains were washed with demineralized water and dried at $70^{\circ} \mathrm{C}$ for $48 \mathrm{~h}$ before being weighed. Litter bags that were torn open or damaged, causing material to be lost, were excluded from analysis ( 5 bags lost, resulting in a total of 175 root litter bags used for analysis).

\section{Aboveground Material}

Freshly senesced aboveground litter was collected from all sites in October 2017. As species composition and thus phenological stages differed between sites, we collected both recently fallen leaves as well as leaves from standing biomass. In the alder forest, we differentiated between alder leaves and leaves of the understory vegetation resulting in two litter type bags for the alder forest. Litter was dried and processed similar to root litter, and cut into $c .1 \mathrm{~cm}$ long pieces if necessary (for example, sedge litter). Litter corresponding to c. $0.54 \mathrm{~g}$ of dry weight was put into nylon bags, which were then packed into frames (size $22 \mathrm{~cm} \times 9 \mathrm{~cm}$, otherwise: see above) and placed on the soil surface in immediate proximity to belowground litter bags (total 120 aboveground litter bags). Aboveground litter frames were installed and retrieved at the same dates as the belowground litter frames.

\section{Tea Bags}

We used commercially available tetrahedronshaped non-woven polypropylene tea bags with sides of $5 \mathrm{~cm}$ containing about $2 \mathrm{~g}$ of green and rooibos tea (Lipton, Unilever) as standard material and followed the protocol by Keuskamp and others (2013). The two types of tea material differ in quality; green tea (Camellia sinensis; EAN no.: 8722700 055525) with high cellulose content being easy to decompose and rooibos tea (Aspalanthus linearis; EAN no.: 8722700 188438) with high lignin content being difficult to decompose (Keuskamp and others 2013). Tea bags were installed in the same 'litter frames' as below- and aboveground litter bags, with one green and one rooibos tea bag for each depth (above ground, 0$10 \mathrm{~cm}, 10-20 \mathrm{~cm}$ and $45-50 \mathrm{~cm}$ ) and replicate (total of 360 green and rooibos tea bags each). After retrieval, the bags were air dried, cleaned of peat and roots, dried at $70^{\circ} \mathrm{C}$ for $48 \mathrm{~h}$, and weighed.

The percentage mass loss (\%ML) was estimated for the root, shoot and leaf material as well as green and rooibos tea:

$$
\% \mathrm{ML}=100-\left[\left(100 \times X_{1}\right) / X_{0}\right]
$$

where $X_{0}$ is the initial dry weight of the material and $X_{1}$ the dry weight after 1 year.

\section{Potential Organic Matter Accumulation}

To arrive at a tentative estimate of OM accumulation potential, we combined production and decomposition estimates from this one-year study period and projected the potential remaining organic matter after one year. For this purpose, we first derived decomposition decay rates ( $k$-values, $\mathrm{y}^{-1}$ ) for root, shoot and leaves from the litter bag experiments using Olson's single-exponential equation (Wieder and Lang 1982; Olson 1963):

$$
\begin{gathered}
X_{t}=X_{0} e^{-k t} \\
k t=-\ln \left(X_{t} / X_{0}\right)
\end{gathered}
$$


Then, the annually produced biomass $\left(\mathrm{g} \mathrm{m}^{-2}\right)$ as derived from in-growth cores and aboveground harvests was inserted as $X_{0}$ to obtain $X_{t}$ for $t=1$ year. For comparison with the aboveground biomass data, we derived a tentative, but conservative value for total root production in the 0 $20 \mathrm{~cm}$ soil layer. We took the measured production at $0-5 \mathrm{~cm}$ and added three times the production measured at $15-20 \mathrm{~cm}$. This conservative approach will have led to an underestimation of the OM accumulation potential of roots. Results need to be interpreted with caution as they represent only the potential of OM accumulation derived from the obtained annual production and decomposition data of this study in this particular year.

We did not calculate the potential of alder wood for OM accumulation, because its decomposition rates are less meaningful over a one-year study period.

\section{Abiotic Parameters}

Soil temperature data were collected using HOBO data loggers (Onset Computer Corporation, Bourne, MA, USA) at 15-min intervals at $5 \mathrm{~cm}$ and $15 \mathrm{~cm}$ depth with six loggers per site. Air temperature was recorded by CR300 data loggers (Campbell Scientific Ltd., Bremen, Germany) and averaged over $30 \mathrm{~min}$. Data were recorded from weather stations set directly at the field sites (one weather station for coastal fens and alder forest, respectively, due to close proximity of the drained and rewetted sites Table 1). Groundwater table relative to the soil surface was recorded at 15-min intervals with a CR300 logger for the two alder stands and by Dipper-PT loggers (SEBA Hydrometrie $\mathrm{GmbH} \&$ Co. KG, Kaufbeuren, Germany) for the two percolation fen sites and the drained coastal fen and by a Baro-Dipper and a Dipper-APT logger (SEBA Hydrometrie GmbH \& Co. KG, Kaufbeuren, Germany) for the rewetted coastal fen site. In the rewetted alder stand, the water table fell below $-70 \mathrm{~cm}$ between 23 August and 27 October 2018 , which exceeded the depth of the groundwater measurement tube at this site (Figure 1).

\section{Data Analysis}

All statistical analyses and visualizations were done in $\mathrm{R}$ version 3.5.3 ( $\mathrm{R}$ Core Team 2019). We tested for differences in each of the following four response variables: biomass production, mass loss, potential of $\mathrm{OM}$ accumulation and the $\Delta \mathrm{ML}_{\text {(roots- }}$ rooibos tea) against the three explanatory variables hydrological status (drained and rewetted), fen type (alder forest, percolation or coastal fen), depth
(0-5 cm or 15-20 cm, only for belowground data), litter type (alder leaves, shoots and roots), and their interactions with linear mixed-effects model ANOVAs [R package LMERTEST, version 3.1-0, Kuznetsova and others (2017)] with plot as a random factor (because there are several measurements on the same plot, at different depths). Prior to statistical analysis we averaged the three data points from each plot to a single value. We conducted the above analysis for all aboveground biomass (shoots and leaves), belowground biomass (roots), and tree stem biomass separately. For the comparison of above- and belowground data, root biomass response variables were integrated over depth (0-20 $\mathrm{cm}$, see above). Tea decomposition data were analysed above- and belowground within a single model, thus the response variable depth was 'aboveground', '0-5 cm', '15-20 cm' and '45$50 \mathrm{~cm}^{\prime}$ in this case.

A Tukey's HSD test [R package emmeans, version 1.3.3, Lenth and others (2019)] was used to test for differences between the wet and dry sites and between the different depths. All data used in the linear models were analysed graphically to test the assumptions of normality and homogeneity of variance, that is, residuals were plotted in normal $q-q$-plots and residual versus fitted plots of the model. If necessary, data were log (biomass production, mass loss of local plant litter and tea, potential of OM accumulation after 5 years), square root (potential of OM accumulation after 1 year) or rank transformed (resulting in a nonparametric test; $\Delta \mathrm{ML}_{\text {(roots-rooibos tea) }}$ ). Visualisations were done using the packages sciplot [version 1.1-1, Morales (2011)] and ggplot2 [version 3.1.1, Wickham (2016)]. Effects were considered significant at $p<0.05$.

\section{RESUlts \\ Plant Biomass Production}

The effect of rewetting on annual biomass production $\left(\mathrm{g} \mathrm{m}^{-2} \mathrm{y}^{-1}\right)$ clearly differed between the three rewetted and the three drained sites (interaction fen type $\times$ hydrological status: aboveground: $F=31.7, \quad p<0.001$; belowground: $F=11.1, p<0.001$, Figure 2A). Except for the shoot production in the coastal fens, production was either similar or higher in the rewetted sites compared to the drained sites. Root production contributed between 23 and $66 \%$ of total biomass production (excluding tree stems) across the different sites. As we did not measure root production below $20 \mathrm{~cm}$ depth, it is very likely that the total 
treatment 审 drained 审 rewetted

A

aboveground
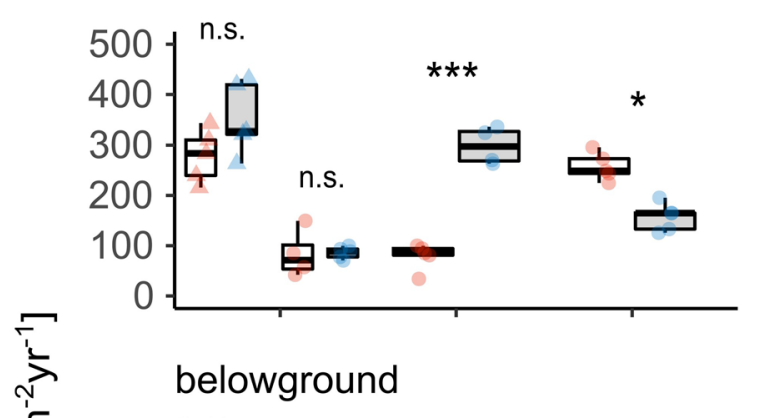

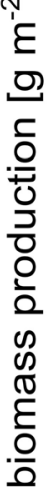

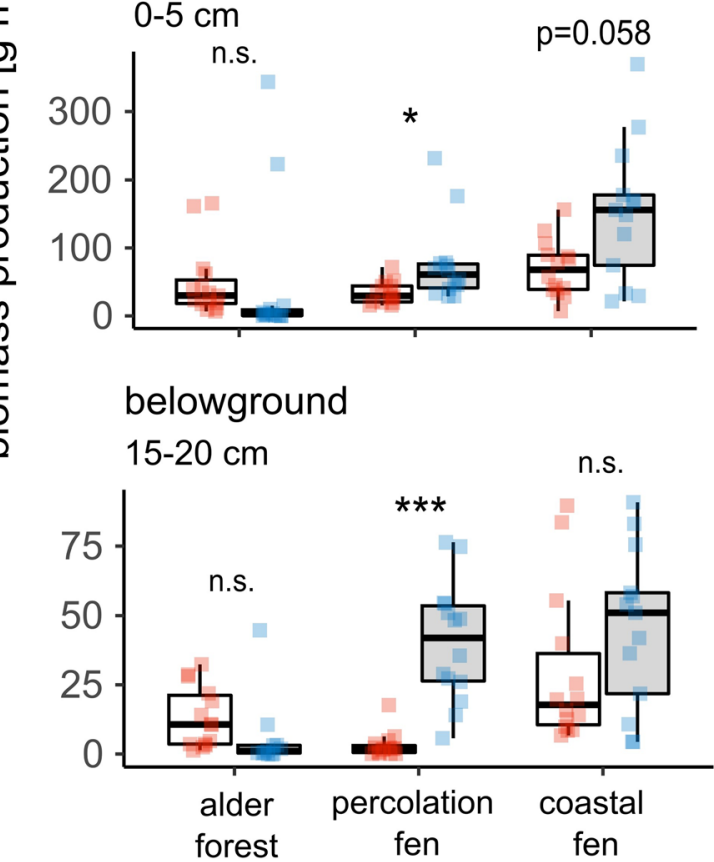

B aboveground

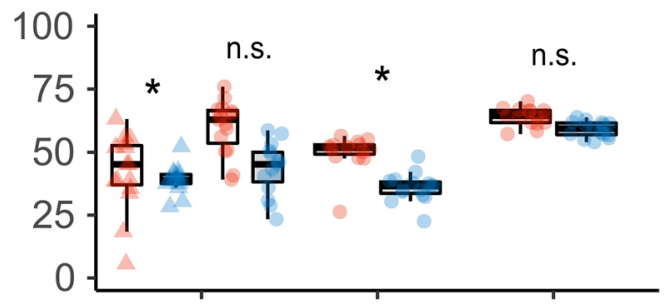

belowground

$0-5 \mathrm{~cm}$

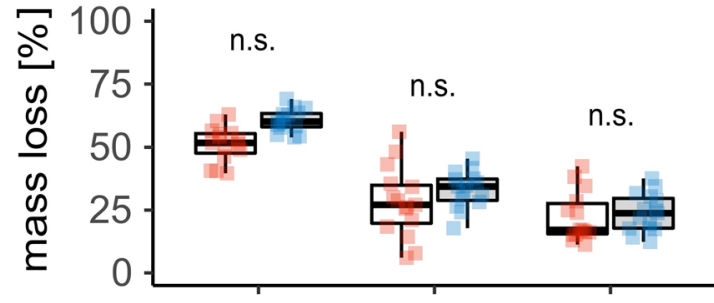

belowground

$15-20 \mathrm{~cm}$

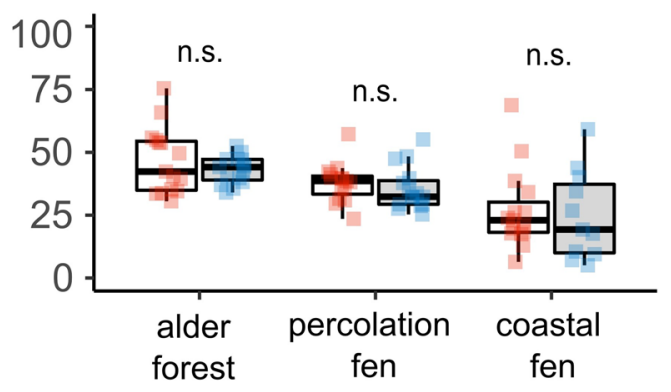

Figure 2. A Annual biomass production $\left(\mathrm{g} \mathrm{m}^{-2} \mathrm{y}^{-1}\right.$, excluding tree stem biomass) measured by shoot harvest, leaf litter traps, and root in-growth cores and $\mathbf{B}$ annual mass loss (\%) measured by litter bags for the fen types alder forest, percolation fen and coastal fen. Displayed are aboveground biomass (that is, shoots $=$ circles, alder leaves $=$ triangles) and belowground biomass (that is, fine roots $\leq 2 \mathrm{~mm}=$ squares) of the two depths $0-5 \mathrm{~cm}$ and $15-20 \mathrm{~cm}$ for the hydrological status drained (white boxes, red symbols) and rewetted (grey boxes, blue symbols). Asterisks and n.s. indicate a significant $\left({ }^{* *} p<0.001,{ }^{* *} p<0.01,{ }^{*} p<0.05\right)$ or non-significant effect $(p>0.05)$ of the hydrological status (drained and rewetted), respectively.

belowground biomass production is even higher. However, root production values from 40 to $45 \mathrm{~cm}$ depth showed 10-100 times lower root production at this depth (Table S3).

In the rewetted percolation fen, both shoot $\left(346 \mathrm{~g} \mathrm{~m}^{-2} \mathrm{y}^{-1}\right)$ and root production (199 $\mathrm{g} \mathrm{m}^{-}$ $\left.{ }^{2} \mathrm{y}^{-1}, 0-20 \mathrm{~cm}\right)$ were significantly higher than in the drained site (shoot: $80 \mathrm{~g} \mathrm{~m}^{-2} \mathrm{y}^{-1}$, root: $43 \mathrm{~g} \mathrm{~m}^{-2} \mathrm{y}^{-1}$ ) (Tukey HSD, $p<0.001$, Table S4). In the coastal fen, shoot production was significantly higher in the drained $\left(257 \mathrm{~g} \mathrm{~m}^{-2} \mathrm{y}^{-1}\right)$ than in the rewetted site $\left(157 \mathrm{~g} \mathrm{~m}^{-2} \mathrm{y}^{-1}\right)$ (Tukey HSD, $p=0.045)$, whereas root production tended to be higher in the rewetted site at $0-5 \mathrm{~cm}$ depth (Tukey HSD, $p=0.058$ ), but not at $15-20 \mathrm{~cm}$ depth (Figure $2 \mathrm{~A}$ ). Root production was significantly higher at the rewetted than at the drained coastal site when root biomass production was integrated over depth (Tukey HSD, $p<0.001$ ). Root production of the rewetted coastal fen was the highest of all sites and made up $66 \%$ of the total biomass production at this site (roots: $300 \mathrm{~g} \mathrm{~m}^{-2} \mathrm{y}^{-1}$, shoots: $157 \mathrm{~g} \mathrm{~m}^{-}$ 
${ }^{2} \mathrm{y}^{-1}$, Table S4). In the alder forest, tree stem biomass production of Alnus glutinosa for the year 2018 was estimated to be more than 4 times higher in the drained site $\left(908.29 \mathrm{~g} \mathrm{~m}^{-2}\right)$ than in the rewetted site $\left(215.47 \mathrm{~g} \mathrm{~m}^{-2}\right) \quad(F=25.7$, $p<0.001)$. Annual leaf production of Alnus measured with litter traps (drained $=223 \mathrm{~g} \mathrm{~m}^{-2} \mathrm{y}^{-1}$, rewetted $=248 \mathrm{~g} \mathrm{~m}^{-2} \mathrm{y}^{-1}$ ) was almost three times higher than understory production (drained $=84$ $\mathrm{g} \mathrm{m}^{-2} \mathrm{y}^{-1}$, rewetted $\left.=86 \mathrm{~g} \mathrm{~m}^{-2} \mathrm{y}^{-1}\right) \quad(F=34.5$, $p<0.001)$. However, no significant differences in annual production of leaves, understory shoots or roots were found between the drained and rewetted alder stand (Figure 2A, Table S4).

\section{Decomposition of Local Plant Material}

Annual mass loss of plant litter (\%ML) differed little between drained and rewetted sites. We measured higher annual \%ML and, therefore, faster decomposition for shoots in the drained alder stand and percolation fen than in the respective rewetted sites (Tukey HSD, alder forest: $p=0.013$; percolation fen: $p=0.014)$. However, there was no significant difference in \%ML of the fine roots between drained and rewetted sites for any of the fen types, despite the different litter material incubated at each site and depth (Figure 2B). In the alder forest, annual \%ML of shoots of the understory was higher than for Alnus leaves (Tukey HSD, $p<0.001$, Figure 2B, Table S4). As expected, $\% \mathrm{ML}$ was site-specific and differed significantly between the three fen types both above- and belowground (above: $F=21.0, p<0.001$; below: $F=47.2, p<0.001$, Figure 2B).

Roots decomposed slower than shoots: In four of the six sites litter decomposition was significantly slower for fine roots than for aboveground biomass; only the rewetted alder stand and rewetted percolation fen showed no significant difference between fine root and shoot decomposition. In the two coastal fens, \%ML of aboveground litter (drained $\mathrm{ML}=64 \%$, rewetted $\mathrm{ML}=56 \%$ ) was about two times higher than for the fine roots (drained: $\mathrm{ML}=29 \%$, rewetted: $\mathrm{ML}=31 \%$ ) (Tukey HSD, $p<0.001)$; in the drained alder stand and percolation fen, \%ML of aboveground litter was 1.5 times higher than for roots (Tukey HSD, alder forest: $p=0.002$; percolation fen: $p<0.001$, Table S4). There was no significant difference in root decomposition between the depths $0-5$ and 15-20 $\mathrm{cm}(F=0.18, p=0.673$; Table 2$)$, except for the rewetted alder stand with faster decomposition in the $0-5 \mathrm{~cm}$ depth (Tukey HSD, $p=0.001$ ). In the rewetted coastal fen, where production was highest

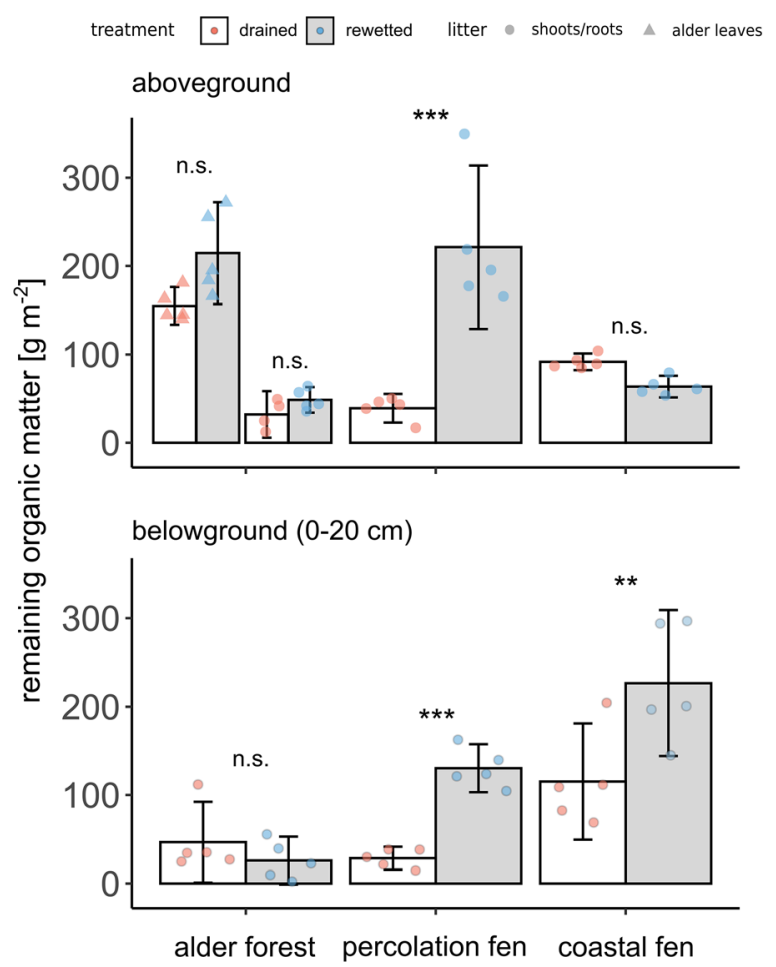

Figure 3. Potentially remaining organic matter $\left(\mathrm{g} \mathrm{m}^{-2}\right)$ after one year for the fen types alder forest, percolation fen and coastal fen and their hydrological status drained (white bars, red symbols) and rewetted (grey bars, blue symbols). An exponential decay model with the measured yearly fine root and shoot production as initial biomass and the estimated decomposition rate $k$ based on \% mass loss of the local plant material was used to project the remaining organic matter (produced over 1 year) after 1 year. Asterisks and n.s. indicate a significant $\left({ }^{* *} p<0.001, \quad{ }^{* *} p<0.01, \quad * p<0.05\right)$ or nonsignificant effect $(p>0.05)$ with the hydrological status (drained and rewetted), respectively. Error bars show the $95 \%$ confidence intervals.

(see above), \%ML was lowest compared with the other sites. In the drained alder stand, the \%ML of the understorey shoot litter $(\mathrm{ML}=60 \%)$ was significantly higher than for alder leaves $(\mathrm{ML}=42 \%)$ (Tukey HSD, $p<0.001$ ), while in the rewetted site there was no difference between the two litter types.

\section{Potential Remaining Organic Matter}

Modelled remaining organic matter $\left(\mathrm{OM}, \mathrm{g} \mathrm{m}^{-2}\right)$ differed between drained and rewetted sites and among the three types of fens (Figure 3). Significant interactions between fen type and hydrological status suggest that the fen type determines in which way rewetting affects potential OM accumulation (aboveground $F=41.0, \quad p<0.001$; 
Table 2. Results of the Interactions of the Linear Mixed-Effects Model ANOVAs for Biomass Production $\left(\mathrm{g} \mathrm{m}^{2} \mathrm{y}^{-1}\right)$, Decomposition of Local Plant Material (Mass Loss in \%), Potential Organic Matter (OM) Accumulation, and $\Delta \mathrm{ML}$ (roots-rooibos tea) Fen Type (Alder Forest, Percolation Fen, Coastal Fen), Hydrological Status (Drained, Rewetted) and Depth $(0-5 \mathrm{~cm}, 15-20 \mathrm{~cm})$ for the Above (=Shoots and Alder Leaves) and the Below Litter (= Roots)

\begin{tabular}{|c|c|c|c|c|c|c|c|c|c|}
\hline \multirow[t]{4}{*}{ Predictors } & \multirow[t]{4}{*}{$d f$} & \multicolumn{8}{|c|}{ Response variables } \\
\hline & & \multicolumn{2}{|c|}{$\begin{array}{l}\text { Biomass } \\
\text { production }\end{array}$} & \multicolumn{2}{|c|}{$\begin{array}{l}\text { Plant } \\
\text { decomposition }\end{array}$} & \multirow{2}{*}{\multicolumn{2}{|c|}{$\begin{array}{l}\begin{array}{l}\text { Potential OM } \\
\text { accumulation }^{\text {a }}\end{array} \\
\text { After l year }\end{array}$}} & \multicolumn{2}{|c|}{$\begin{array}{l}\Delta M L_{\text {(roots-rooibos }} \\
\text { tea) }\end{array}$} \\
\hline & & \multirow[t]{2}{*}{$F$} & \multirow[t]{2}{*}{$p$} & \multirow[t]{2}{*}{$F$} & \multirow[t]{2}{*}{$p$} & & & \multirow[t]{2}{*}{$F$} & \multirow[t]{2}{*}{$p$} \\
\hline & & & & & & $F$ & $p$ & & \\
\hline \multicolumn{10}{|l|}{ Shoots and leaves } \\
\hline Fen type & 2 & 2.08 & 0.143 & 20.96 & $<0.001$ & 4.96 & 0.014 & - & - \\
\hline Hydrological status & 1 & 39.46 & $<0.001$ & 11.91 & $<0.001$ & 63.69 & $<0.001$ & - & - \\
\hline Fen type $\times$ hydrological status & 2 & 31.71 & $<0.001$ & 2.52 & 0.097 & 41.04 & $<0.001$ & - & - \\
\hline Shoots-leaves & 1 & 34.46 & $<0.001$ & 30.15 & $<0.001$ & 131.89 & $<0.001$ & - & - \\
\hline \multicolumn{10}{|l|}{ Roots } \\
\hline Fen type & 2 & 19.88 & $<0.001$ & 47.23 & $<0.001$ & 25.26 & $<0.001$ & 99.02 & $<0.001$ \\
\hline Hydrological status & 1 & 3.06 & 0.087 & 0.03 & 0.855 & 13.70 & 0.001 & 1.22 & 0.276 \\
\hline Depth & 1 & 33.38 & $<0.001$ & 0.18 & 0.673 & - & - & 0.51 & 0.479 \\
\hline Fen type $\times$ hydrological status & 2 & 11.14 & $<0.001$ & 0.55 & 0.579 & 9.28 & 0.001 & 2.43 & 0.095 \\
\hline fen type $\times$ hydrological status $\times$ depth & 2 & 0.22 & 0.802 & 0.03 & 0.968 & - & - & 4.58 & 0.016 \\
\hline Fen type $\times$ depth & 2 & 0.12 & 0.884 & 4.31 & 0.019 & - & - & 5.40 & 0.008 \\
\hline Hydrological status $\times$ depth & 1 & 0.19 & 0.663 & 3.96 & 0.053 & - & - & 10.74 & 0.002 \\
\hline Shoots/leaves-roots & 1 & 12.56 & $<0.001$ & 63.04 & $<0.001$ & 1.83 & 0.181 & - & - \\
\hline
\end{tabular}

belowground $F=9.3, p=0.001)$. The rewetted sites showed an overall higher potential for remaining OM than the drained sites (aboveground: $F=63.7, \quad p<0.001$; belowground: $F=13.7, p=0.001$ ).

The potential for accumulating OM did not differ significantly between above- and belowground biomass $(F=1.8, p=0.181)$, but this difference depended on the litter type. In both alder stands, the estimated OM remaining for alder leaves was highest compared with shoots of the understory (Tukey HSD, $p<0.001$ ) or with roots (Tukey HSD, $p<0.001)$. For roots, only small or even nonsignificant amounts of $\mathrm{OM}$ were projected to remain (95\% confidence intervals overlap with zero). In both percolation fens, there was no significant difference between the remains of shoot and roots. However, higher remains of OM were projected for roots than for shoots in the drained (Tukey HSD, $p=0.026$ ) and the rewetted coastal fen (Tukey HSD, $p<0.001)$. The rewetted percolation fen seemed to have the overall highest potential for accumulating above- and belowground OM, while the drained percolation seemed to have the overall lowest potential.

\section{Decomposition of Standard Material}

Green tea decomposed faster than rooibos tea in all cases (Figure 4, Table S5). Against expectation, $\%$ ML was not always higher in the drained than in the rewetted sites, nor was there a clear trend with depth. Differences between the drained and rewetted sites were most pronounced in the belowground buried tea bags and less so aboveground (hydrological status $\times$ depth, $F=20.8$, $p<0.001$, Figure 4).

\section{Decomposability of Different Litter Materials}

The decomposability of root material versus rooibos tea depended strongly on the fen type $(F=76.5$, $p<0.001$; Figure 5). In the alder stands, fine roots decomposed faster and in the coastal fens slower than the rooibos tea, but we found no significant difference between the two depths $(0-5 \mathrm{~cm}, 15-$ 
$20 \mathrm{~cm}$ ) or the hydrological status for these two fen types (Figure $5 \mathrm{~A}, \mathrm{C})$. In the drained percolation fen roots decayed slower $(0-5 \mathrm{~cm})$ or faster $(15-20 \mathrm{~cm})$ than rooibos tea (Tukey HSD, $p<0.001$; Figure $5 \mathrm{~B}$ ). In the rewetted percolation fen, we did not observe a significant difference with depth, but fine roots in the rewetted site decomposed faster than rooibos tea in the upper layer and slower in the deeper layer compared to the drained site (Tukey HSD, $0-5 \mathrm{~cm}: \quad p<0.001 ; 15-20 \mathrm{~cm}$ : $p=0.022$; Figure 5B).

\section{Abiotic Parameters}

Sites shared same macroclimate, but differed in their microclimatic conditions. Due to the extreme warm and drought conditions in the year 2018, water table drawdown in the rewetted sites was up to $30 \mathrm{~m}$ below surface in the rewetted percolation fen (Figure 1B) and even $80 \mathrm{~cm}$ in the rewetted alder stand and coastal fen (Figure 1A, C). However, the rewetted sites had higher water tables than the drained sites, resulting in an almost two times higher number of water saturated days (over all depths, rewetted: $c$ 191 days; drained: $c$ 100 days; Table S1). Mean annual air temperatures across all sites varied between 9.3 and $9.9^{\circ} \mathrm{C}$, whereas soil temperatures varied between 8.1 and $10.2^{\circ} \mathrm{C}$ (Figure 1, Table S1).

\section{Discussion}

\section{Plant Biomass Production}

Rewetted sites had higher biomass production than their drained counterparts in the percolation fen, a higher aboveground biomass production and similar belowground biomass production in the coastal fen, and similar understory and leaf production in the alder stands (Figure 2A), supporting our hypothesis that rewetting creates conditions beneficial for plant production under dry conditions. Higher production through rewetting may seem controversial, the more so, because we compare with drained systems where vegetation was selected for high yields as part of their use as intensive grasslands (percolation fen) and production forest (alder forest). High water tables are known to inhibit plant growth by limiting the availability of oxygen needed for respiration and lowering the redox potential affecting the uptake of nutrients (Voesenek and others 2006; Lambers and others 2008). However, periodically flooded or even permanently water saturated soils with anoxic conditions induce a plant community composed of species that are adapted to these conditions
(Mäkiranta and others 2018) and that can have high yields (Oehmke and Abel 2016). A common adaptation of plants to flooding is the formation of aerenchyma (that is, tissue containing enlarged gas spaces) (Moore and Garratt 2006; Voesenek and others 2006). This adaptation is evident in numerous species present in our studied peatlands (for example, Alnus glutinosa, Carex spp., Juncus sp., Phalaris arundinacea) and enables them to transport oxygen into the otherwise anoxic rhizosphere allowing for root growth deep into waterlogged soils (Evans 2004; Blom and Voesenek 1996; Schröder 1989; Voesenek and others 2006).

Such adaptations of the established plant community are most likely the reason why the rewetted percolation fen had high production, although the water table remained close to the surface for the entire measurement period. These wet conditions during the warm and dry year of 2018 rather seem to have been more favourable for biomass production than the potentially too dry conditions at the other sites. The rewetted coastal site was just as dry as the drained site during the growing season and we observed no clear difference in production here. The water table in the rewetted alder stand was considerably higher than in the drained stand, but during the summer months still (very) deep (Figure 1), not leading to any differences in biomass production between the alder stands.

The positive effect rewetting seems to have on the production of plant biomass in the percolation fen, despite of the observed water table drawdown in 2018, suggests that rewetting creates moister soil conditions beneficial for plant productivity in dry years. Rewetted peatlands may thus better cope with droughts, which are projected to increase with climate change (IPCC 2013). Mäkiranta and others (2018) found no significant change in the biomass production of sedges after moderate warming and water table drawdown in boreal fens, while forbs decreased and shrubs increased. Wet(ter) peatlands, such as our sedge-dominated percolation fen, may therefore tolerate future warmer and drier conditions better than, for example, drained forb or grass dominated fens.

\section{Decomposition of Local Plant Biomass}

We found lower shoot decomposition rates in the rewetted alder stand and percolation fen than in their drained counterparts but rates did not differ between the drained and rewetted coastal sites. Higher decomposition rates in the drained sites had been expected, as more oxygen would be available for decomposing microorganisms, facilitating the 
decay of OM (Denny 1993; Freeman and others 2001; Moore and Garratt 2006; Moore and others 2007). Yet, water tables were mostly below the soil surface during summer months. As decomposition of standard material and alder leaves hardly differed between the drained and rewetted sites, plant shoots in the rewetted alder stand and percolation fen are apparently less easily decomposed than shoots of the drained sites.

With respect to belowground biomass, no difference was found in root decomposition between any of the respective drained and rewetted fen types (Figure 2B), even though the rewetted sites clearly had higher water tables, resulting in an almost two times higher number of water saturated days (over all depths, rewetted: c. 191 days; drained c. 100 days, Table S1). A reason for this could be that though generally higher in rewetted sites, water tables were low during the summer months, particularly in both drained and rewetted alder and coastal sites. Nevertheless, water tables were high also during summer in the rewetted percolation fen (above $-20 \mathrm{~cm}$ for c. $70 \%$ of the time between April and October), while soil temperatures were lower (Figure 1B). That still no difference was found in decomposition of belowground biomass could be due to drought stress resulting in reduced decomposition in the drained site (Mäkiranta and others 2008).

Different patterns in shoot and root decomposition imply that studies focussing only on decomposition of aboveground litter miss important aspects of organic matter dynamics. For instance, we found no significant difference in decomposition of roots and leaf litter between drained and rewetted sites, but shoot decomposition was significantly higher in the drained alder stand (understory) and the drained percolation fen (Figure 2B, Table S4). Thus, the type of litter determines to some degree how fast it is decomposed (Table 2). Unlike shoots or leaves, roots of adapted plants, grow even into anoxic soil layers making them harder to decompose for aerobic microorganisms upon root death. This makes them better candidates to accumulate as $\mathrm{OM}$ and underlines that roots are potentially more important for peat formation than aboveground litter material.

It appears that differences in vegetation composition, and therefore litter quality, in relation to hydrologic status can have strong effects on litter decomposition. Incubation of standard material showed that environmental factors, such as temperature and water saturation, are important drivers of litter decomposition in these systems (see below), but that these are obviously offset by changes in local plant material. Decomposition rates differed between plant materials; shoots of the understory were more easily decomposed than $\mathrm{Al}$ nus leaves in the alder forest (Figure 2B, Table S4). Zhang and others (2008) similarly reported higher decomposition rates for grass leaves than for broadleaved litter, which they determined were caused by differences in litter quality (that is, C:N, total nutrient content, lignin content), one of the most important direct regulators of litter decomposition. In contrast to our findings, the global assessment of Freschet and others (2013) found lower decomposition rates for fine roots and stems than for leaves.

\section{Potential Remaining Organic Matter}

Based on production and decomposition rates of 2018, we tentatively modelled how much of the produced organic matter would theoretically remain of the annual produced biomass measured after one year. Note that 2018 was a dry and warm year at our sites, implying that this year does not reflect historic conditions but instead might reflect future conditions in the light of ongoing climate change (IPCC 2013). Under these conditions, the rewetted percolation fen and both coastal sites showed the highest potential for OM accumulation. Interestingly, high potentials of $\mathrm{OM}$ accumulation were not caused by lower decomposition rates in the respective sites, but rather by higher annual biomass production (Figure 3). The high potential in the rewetted compared to the low potential of the drained percolation fen gives an idea of how effective rewetting can be in restoring peat-forming conditions after drainage [see also Mrotzek and others (2020)]. Indeed, decomposition rates of the sites with the highest accumulation potential are only half as high as in sites with low potentials, such as the alder forest (Table S4). In fact, the alder forest's potential in accumulating OM appears to be low compared to the other sites and equalled zero belowground after only one year.

Alder wood peats are known for their high degree of decomposition (Barthelmes and others 2006; Prager and others 2006) as a result of improved nutrient availability due to the symbiotic relationship of Alnus glutinosa with nitrogen-fixing bacteria (Frankia alni), oxygen enrichment of deeper peat layers via Alnus roots (Claessens and others 2010), and typically fluctuating water levels (Succow and Joosten 2001). This 'fertilization' of the soil promotes turnover and leads to high rates of decomposition (Swanston and Myrold 1997). 
Highest long-term rates of peat accumulation of 50 to $126 \mathrm{~g} \mathrm{C} \mathrm{m}^{-2} \mathrm{y}^{-1}$ have been shown to occur in alder forests with water tables slightly below the surface when production is stimulated and decay not as much; those accumulation rates are even higher or comparable to the $48-96 \mathrm{~g} \mathrm{C} \mathrm{m}^{-2} \mathrm{y}^{-1}$ of sedge peats (Prager and others 2006; Barthelmes and others 2006). However, for our dry and warm study period, higher accumulation of OM in the rewetted site could not be validated as the water table in both drained and rewetted alder stands dropped strongly.

Our projections show that the importance of litter type (that is, shoots vs. roots) for peat accumulation cannot be generalised or only projected from aboveground litter for those fen ecosystems. While almost no $\mathrm{OM}$ is projected to remain from roots after one year in the alder stands, roots are of special importance in the two coastal fens where their potential for OM accumulation exceeds that of shoots. This emphasizes the importance of roots for peat formation in these coastal ecosystems, at least during dry years. In fact, the potential for belowground biomass for peat formation may be even higher, because we only measured root pro- duction until $20 \mathrm{~cm}$ depth and interpolated conservatively between $0-5$ and $15-20 \mathrm{~cm}$ depth.

\section{Decomposition of Standard Material}

We compared decomposition of standard material with autochthonous root material to disentangle if environmental factors or rather differences in root litter quality between soil depths cause depthspecific differences in root decomposition. We focused on roots, because we expected different roots in different depths (for example, chemical differences between deep and shallow fine roots, differing rooting depth between species).

We expected to find lower decomposition rates in rewetted sites and with increasing soil depth, due to higher probability of water saturated conditions and declining temperatures in deeper depths. Indeed, the amount of water saturated days increased and temperature decreased with increasing soil depth (Figure 1, Table S1). Yet, decomposition rates of the standard material only decreased with increasing depth in the alder forest (Figure 4A) and not in the other peatland types. While we found significant differences between drained and rewetted sites for the buried tea bags, these differ-

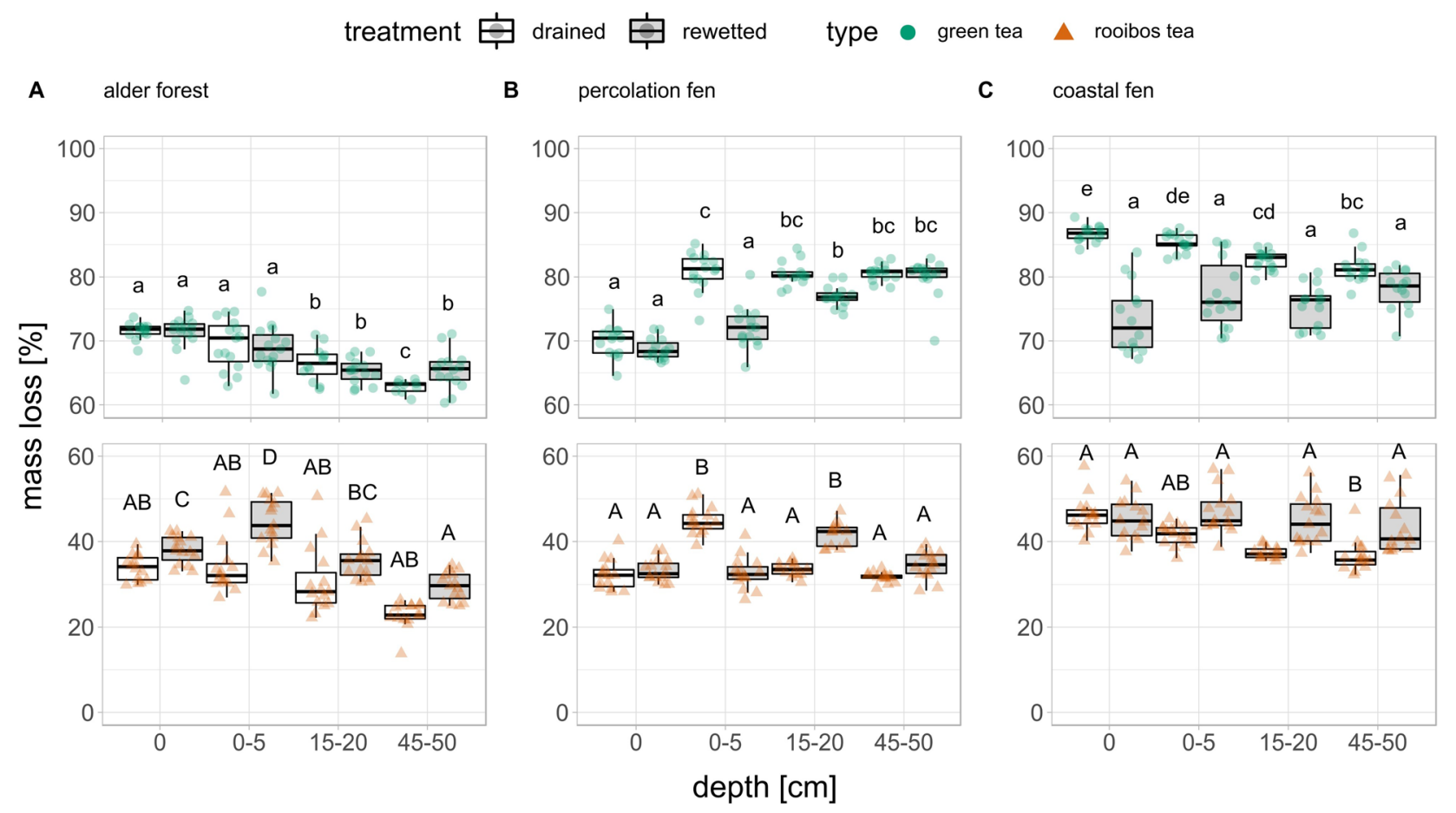

Figure 4. Mass loss in \% for the standard materials green (dots, upper panels) and rooibos tea (triangles, lower panels) for the fen types alder forest $(\mathbf{A})$, percolation fen $(\mathbf{B})$ and coastal fen $(\mathbf{C})$ and the hydrological status drained (white boxes) and rewetted (grey boxes). Displayed are the different depths in which the tea bags were buried, including aboveground $(=0)$, and the soil depths $(0-5 \mathrm{~cm}, 15-20 \mathrm{~cm}$ and $45-50 \mathrm{~cm})$. Values with the same letter within a tea type are not significantly different ( $p \geq 0.05$, Tukey's HSD test). 


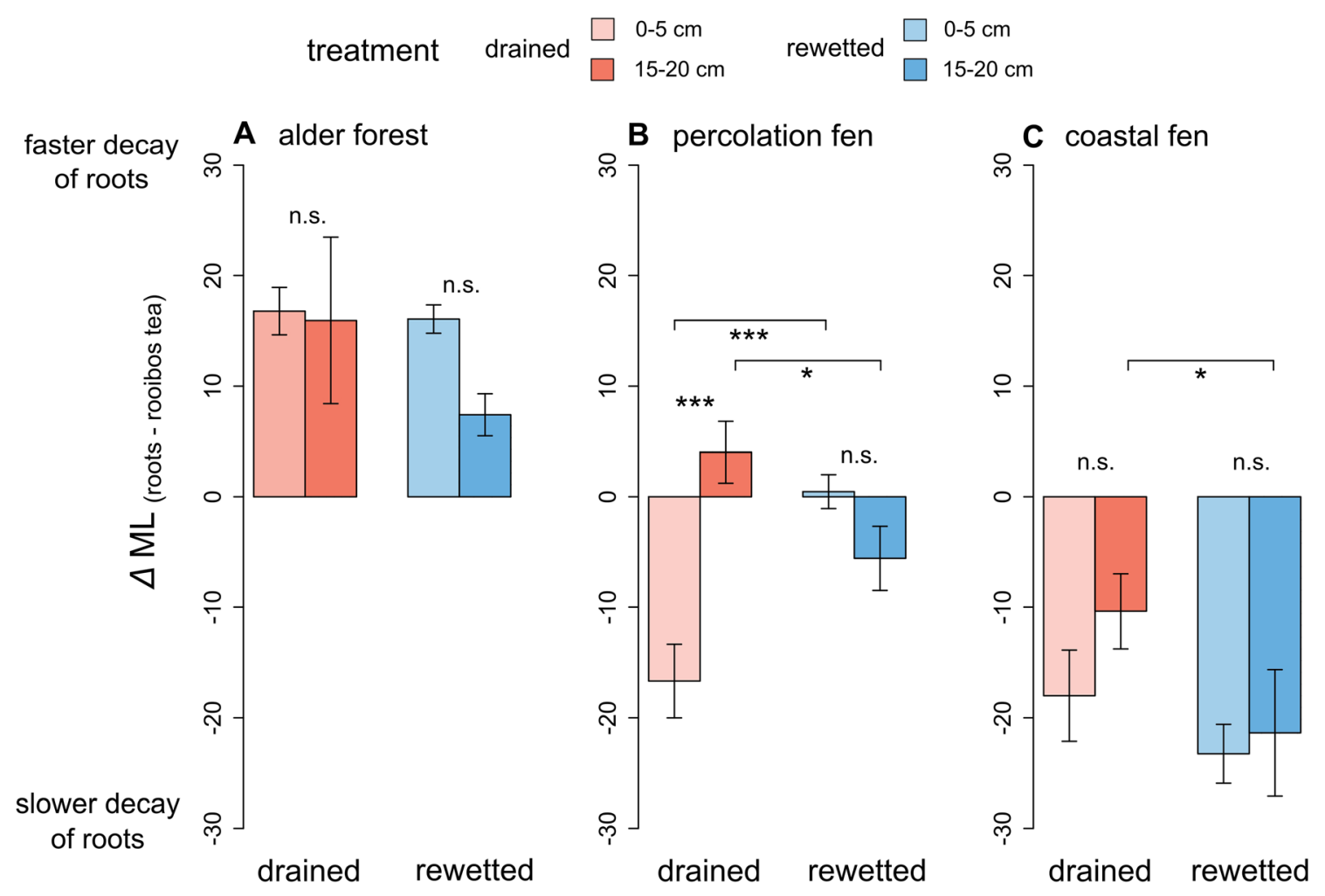

Figure 5. Comparison of decomposition of fine roots and rooibos tea for the fen types alder forest (A), percolation fen $(\mathbf{B})$ and coastal fen $(\mathbf{C})$ in the two depths $0-5 \mathrm{~cm}$ (drained: bright red bars, rewetted: bright blue bars) and 15-20 $\mathrm{cm}(\mathrm{drained}$ : dark red bars, rewetted: dark blue bars). Difference in mass loss between fine root litter and rooibos tea $\left(\Delta \mathrm{ML}_{\text {(roots-rooibos tea) }}\right)$ showing whether decomposition was faster $(>0)$ or slower $(<0)$ for roots than for tea. Asterisks and n.s. indicate a significant effect $\left({ }^{* *} p<0.001,{ }^{* *} p<0.01,{ }^{*} p<0.05\right)$ or non-significant effect $(p>0.05)$ with the hydrological status (drained and rewetted) and the depths $(0-5 \mathrm{~cm}$ and $15-20 \mathrm{~cm}$, brackets) on decomposition, respectively. Error bars show standard error.

ences did not follow our expectations to always be higher in the drained than in the rewetted sites (Figure 4, Table S5). Yet, root litter decomposition did not differ between our drained and rewetted sites. This discrepancy indicates that the litter quality of the vegetation present may override the effects of environmental factors such as water table and soil temperature, as previously found for Carex spp. and Phragmites australis (Hartmann 1999). Indeed, how fast or slow local root material was decomposed compared to the standard material (that is, rooibos tea) depended on the fen type. Hence, local plant material differed in terms of its decomposability. Furthermore, the decomposability of the root material, but not the standard material, depended on soil depth. Such differences may be driven by a differing rooting depth between species, and thus a change in 'species composition' in the root material in different depths, or by changes in root chemical composition with depth (for example, greater nitrogen concentrations in shallow roots), even within the same plant species (Pregitzer and others 1997; Burton and others 2012). These aspects stress the importance of using autochthonous litter material to estimate decomposition rates, even at different soil depths, if the goal is to measure realized and not theoretical decomposition rates of the ecosystems.

\section{Conclusions}

Our findings suggest that during warm and dry conditions high rates of biomass production and not exclusively low litter decomposition are an important driver of $\mathrm{OM}$ accumulation in rewetted minerotrophic peatlands. Based on these results, rewetted peatlands may cope better with the extreme weather conditions that will occur more frequently in the future than their drained counterparts, emphasizing the case for rewetting those systems with respect to carbon storage even during dry periods when soils are not water saturated. The 
importance of belowground OM compared to aboveground OM differed between fen types in our projections, highlighting the importance of roots as main peat-forming element in graminoid-dominated fen peatlands compared to alder dominated forest peatlands and their crucial role in C cycling.

\section{ACKNOWLEDGEMENTS}

This study was supported by the European Social Fund (ESF) and the Ministry of Education, Science and Culture of Mecklenburg-Western Pomerania within the scope of the project WETSCAPES (ESF/ 14-BM-A55-0035/16). We thank the whole Wetscapes consortium for their contribution to this study by providing data and expertise. We also thank Birgit Schröder for conducting the vegetation surveys on our sites. Especially, we thank Tobias Scharnweber for providing leaf production data in the two alder forests stands, Laurenz Teuber for providing weather data and water table depths, Anke Günther for the soil temperature data, Wakene Negassa Chewaka for providing data on bulk density and available plant nutrients, and Florian Beyer for his help in illustrating that our study sites are representative for their fen type. We further want to thank our numerous student workers for washing roots and contribute largely to our fieldwork.

\section{FUNDING}

Open Access funding enabled and organized by Projekt DEAL.

\section{OPEN ACCESS}

This article is licensed under a Creative Commons Attribution 4.0 International License, which permits use, sharing, adaptation, distribution and reproduction in any medium or format, as long as you give appropriate credit to the original author(s) and the source, provide a link to the Creative Commons licence, and indicate if changes were made. The images or other third party material in this article are included in the article's Creative Commons licence, unless indicated otherwise in a credit line to the material. If material is not included in the article's Creative Commons licence and your intended use is not permitted by statutory regulation or exceeds the permitted use, you will need to obtain permission directly from the copyright holder. To view a copy of this licence, visit $h$ ttp://creativecommons.org/licenses/by/4.0/.

\section{REFERENCES}

Aerts R. 1997. Climate, leaf litter chemistry and leaf litter decomposition in terrestrial ecosystems: a triangular relationship. Oikos 79:439-49.

Barthelmes A, Gerloff D, de Klerk P, Joosten H. 2010. Short-term vegetation dynamics of Alnus dominated peatlands: a high resolution palaeoecological case study from Western Pomerania (NE Germany). Folia Geobot 45:279-302. https://d oi.org/10.1007/s12224-010-9063-8.

Barthelmes A, Prager A, Joosten H. 2006. Palaeoecological analysis of Alnus wood peats with special attention to nonpollen palynomorphs. Rev Palaeobot Palynol 141:33-51.

Bérubé V, Rochefort L. 2018. Production and decomposition rates of different fen species as targets for restoration. Ecol Indic 91:105-15.

Blom C, Voesenek L. 1996. Flooding: the survival strategies of plants. Trends Ecol Evol 11:290-5.

Bonn A, British Ecological Society (Eds.). 2016. Peatland restoration and ecosystem services: science, policy, and practice. Cambridge: Cambridge University Press.

Burton AJ, Jarvey JC, Jarvi MP, Zak DR, Pregitzer KS. 2012. Chronic $\mathrm{N}$ deposition alters root respiration-tissue $\mathrm{N}$ relationship in northern hardwood forests. Glob Change Biol 18:258-66.

Claessens H, Oosterbaan A, Savill P, Rondeux J. 2010. A review of the characteristics of black alder (Alnus glutinosa (L.) Gaertn.) and their implications for silvicultural practices. Forestry 83:163-75.

Denny MW. 1993. Air and water: the biology and physics of life's media. Princeton: Princeton University Press.

Djukic I, Kepfer-Rojas S, Schmidt IK, Larsen KS, Beier C, Berg B, Verheyen K. 2018. Early stage litter decomposition across biomes. Sci Total Environ 628-629:1369-94.

Domisch T, Finér L, Laine J, Laiho R. 2006. Decomposition and nitrogen dynamics of litter in peat soils from two climatic regions under different temperature regimes. Eur J Soil Biol 42:74-81

Evans DE. 2004. Aerenchyma formation. New Phytol 161:3549.

Fenner N, Freeman C. 2011. Drought-induced carbon loss in peatlands. Nat Geosci 4:895-900.

Freeman C, Ostle N, Kang H. 2001. An enzymic'latch'on a global carbon store. Nature 409:149.

Freschet GT, Cornwell WK, Wardle DA, Elumeeva TG, Liu W, Jackson BG, Onipchenko VG, Soudzilovskaia NA, Tao J, Cornelissen JHC, Austin A. 2013. Linking litter decomposition of above- and below-ground organs to plant-soil feedbacks worldwide. J Ecol 101:943-52.

Graf M, Rochefort L. 2015. Examining the peat-accumulating potential of fen vegetation in the context of fen restoration of harvested peatlands. Écoscience 16:158-66.

Günther A, Huth V, Jurasinski G, Glatzel S. 2015. The effect of biomass harvesting on greenhouse gas emissions from a rewetted temperate fen. GCB Bioenergy 7:1092-106.

Guo D, Xia M, Wei X, Chang W, Liu Y, Wang Z. 2008. Anatomical traits associated with absorption and mycorrhizal colonization are linked to root branch order in twenty-three Chinese temperate tree species. New Phytol 180:673-83.

Hartmann M. 1999. Species dependent root decomposition in rewetted fen soils. Plant Soil 213:93-8. 
Hobbie SE, Oleksyn J, Eissenstat DM, Reich PB. 2010. Fine root decomposition rates do not mirror those of leaf litter among temperate tree species. Oecologia 162:505-13.

IPCC. 2013. Climate change 2013: the physical science basis. Contribution of working group I to the fifth assessment report of the intergovernmental panel on climate. Cambridge: Cambridge University Press

Joosten H, Clarke D. 2002. Wise use of mires and peatlands. Chicago: International Mire Conservation Group and International Peat Society. p 304.

Joosten H, Couwenberg J. 2008. Peatlands and carbon. In: Parish F, Sirin A, Charman D, Joosten H, Minaeva T, Silvius M, Eds. Assessment on peatlands, biodiversity and climate change. Wageningen: Global Environment Centre, Kuala Lumpur and Wetlands International. p 99-117.

Joosten H. 2009. The Global Peatland CO2 Picture: peatland status and drainage related emissions in all countries of the world. In: The Global Peatland CO2 Picture: peatland status and drainage related emissions in all countries of the world.

Joosten H, Sirin A, Couwenberg J, Laine J, Smith P. 2016. The role of peatlands in climate regulation In: Bonn A, Allott T, Evans M, Joosten H, Stoneman R, Eds. Peatland Restoration and Ecosystem Services. Cambridge: Cambridge University Press, pp 63-76.

Joosten H, Tanneberger F, Moen A. 2017. Mires and peatlands of Europe. Status, distribution and conservation. Stuttgart: Schweizerbart Science Publishers.

Jurasinski G, Ahmad S, Anadon-Rosell A, Berendt J, Beyer F, Bill R, Blume-Werry G, Couwenberg J, Günther A, Joosten H, Koebsch F, Köhn D, Koldrack N, Kreyling J, Leinweber P, Lennartz B, Liu H, Michaelis D, Mrotzek A, Negassa W, Schenk S, Schmacka F, Schwieger S, Smiljanić M, Tanneberger $\mathrm{F}$, Teuber $\mathrm{L}$, Urich $\mathrm{T}$, Wang $\mathrm{H}$, Weil $\mathrm{M}$, Wilmking $\mathrm{M}$, Zak D, Wrage-Mönnig N. 2020. From understanding to sustainable use of peatlands: the WETSCAPES approach. Soil Syst 4:14. https://www.mdpi.com/2571-8789/4/1/14.

Keuskamp JA, Dingemans BJJ, Lehtinen T, Sarneel JM, Hefting MM, Muller-Landau H. 2013. Tea Bag Index. A novel approach to collect uniform decomposition data across ecosystems. Methods Ecol Evol 4:1070-5.

Kirchner A. 1971. Ein Beitrag zur Klassifizierung von Niedermoorstandorten in den drei Nordbezirken der DDR unter für die Melioration bedeutungsvollen hydrologischen Gesichtspunkten. (Unpublished doctoral dissertation). Rostock, Germany.

Koch J, Siemann A, Stisen S, Sheffield J. 2016. Spatial validation of large-scale land surface models against monthly land surface temperature patterns using innovative performance metrics. J Geophys Res Atmos 121:5430-52. https://doi.org/ 10.1002/2015JD024482

Koch S, Jurasinski G, Koebsch F, Koch M, Koch M, Glatzel S, Glatzel S. 2014. Spatial variability of annual estimates of methane emissions in a Phragmites Australis (Cav.) Trin. ex Steud. Dominated restored Coastal Brackish Fen. Wetlands 34:593-602. https://doi.org/10.1007/s13157-014-0528-z.

Kuznetsova A, Brockhoff PB, Christensen RHB. 2017. lmerTest Package: tests in Linear mixed effects models. J Stat Softw 82:1-26.

Laiho R. 2006. Decomposition in peatlands. Reconciling seemingly contrasting results on the impacts of lowered water levels. Soil Biol Biochem 38:2011-24.

Laiho R, Laine J, Trettin CC, Finér L. 2004. Scots pine litter decomposition along drainage succession and soil nutrient gradients in peatland forests, and the effects of inter-annual weather variation. Soil Biol Biochem 36:1095-109.

Lambers H, Chapin FSIII, Pons TL. 2008. Plant physiological ecology. Berlin: Springer.

Lamers LPM, Vile MA, Grootjans AP, Acreman MC, van Diggelen R, Evans MG, Richardson CJ, Rochefort L, Kooijman AM, Roelofs JGM, Smolders AJP. 2015. Ecological restoration of rich fens in Europe and North America: from trial and error to an evidence-based approach. Biol Rev Camb Philos Soc 90:182-203.

Leifeld J, Wüst-Galley C, Page S. 2019. Intact and managed peatland soils as a source and sink of GHGs from 1850 to 2100 . Nat Clim Change 9:945-7.

Lenth R, Singmann H, Love J, Buerkner P, Herve M. 2019. emmeans: Estimated Marginal Means, aka Least-Squares Means (Version 1.3. 4).

Lieffers VJ. 1988. Sphagnum and cellulose decomposition in drained and natural areas of an Alberta peatland. Can J Soil Sci 68:755-61.

Mäkiranta P, Laiho R, Mehtätalo L, Straková P, Sormunen J, Minkkinen K, Penttilä T, Fritze H, Tuittila E-S. 2018. Responses of phenology and biomass production of boreal fens to climate warming under different water-table level regimes. Glob Change Biol 24:944-56.

Mäkiranta P, Minkkinen K, Hytönen J, Laine J. 2008. Factors causing temporal and spatial variation in heterotrophic and rhizospheric components of soil respiration in afforested organic soil croplands in Finland. Soil Biol Biochem 40:1592600 .

McCormack LM, Eissenstat DM, Prasad AM, Smithwick Erica A H. 2013. Regional scale patterns of fine root lifespan and turnover under current and future climate. Glob Change Biol 19:1697-708.

McCormack ML, Dickie IA, Eissenstat DM, Fahey TJ, Fernandez CW, Guo D, Helmisaari H-S, Hobbie EA, Iversen CM, Jackson RB, Leppälammi-Kujansuu J, Norby RJ, Phillips RP, Pregitzer KS, Pritchard SG, Rewald B, Zadworny M. 2015. Redefining fine roots improves understanding of below-ground contributions to terrestrial biosphere processes. New Phytol 207:505-18.

McVean DN. 1956. Ecology of Alnus glutinosa (L.) Gaertn: IV. root system. J Ecol 44:219-25.

Meentemeyer V, Berg B. 1986. Regional variation in rate of mass loss of Pinus sylvestris needle litter in Swedish pine forests as influenced by climate and litter quality. Scand J For Res $1: 167-80$

Meier EW. 2015. Identifying and using hundreds of woods worldwide. Wood database. https://www.wood-database.co $\mathrm{m} /$.

Michaelis D, Mrotzek A, Couwenberg J. 2020. Roots, tissues, cells and fragments-how to characterize peat from drained and rewetted fens. Soil Syst 4:12. https://www.mdpi.com/25 71-8789/4/1/12

Minkkinen K, Vasander H, Jauhiainen S, Karsisto M, Laine J. 1999. Post-drainage changes in vegetation composition and carbon balance in Lakkasuo mire, Central Finland. Plant Soil 207:107-20.

Moore PD, Garratt R. 2006. Wetlands. New York: Chelsea House.

Moore TR, Bubier JL, Bledzki L. 2007. Litter decomposition in temperate peatland ecosystems. The effect of substrate and site. Ecosystems 10:949-63. 
Morales M. 2011. Sciplot: scientific graphing functions for factorial designs. $\mathrm{R}$ package version, 1-0.

Mrotzek A, Michaelis D, Günther A, Wrage-Mönnig N, Couwenberg J. 2020. Mass balances of a drained and a rewetted peatland: on former losses and recent gains. Soil Syst 4:16. https://www.mdpi.com/2571-8789/4/1/16.

Oehmke C, Abel S. 2016. Promising plants for paludiculture. In: Paludiculture-productive use of wet peatlands. Climate protection-biodiversity-regional economic benefits. Stuttgart: Schweizerbart Science Publishers. pp 22-38.

Olson JS. 1963. Energy storage and the balance of producers and decomposers in ecological systems. Ecology 44:322-31.

Parton W, Silver WL, Burke IC, Grassens L, Harmon ME, Currie WS, King JY, Adair EC, Brandt LA, Hart SC, Fasth B. 2007. Global-scale similarities in nitrogen release patterns during long-term decomposition. Science (New York, N.Y.) 315:3614.

Pendall E, Bridgham S, Hanson PJ, Hungate B, Kicklighter DW, Johnson DW, Law BE, Luo Y, Megonigal JP, Olsrud M, Ryan MG, Wan S. 2004. Below-ground process responses to elevated $\mathrm{CO} 2$ and temperature. A discussion of observations, measurement methods, and models. New Phytol 162:311-22.

Prager A, Barthelmes A, Theuerkauf M, Joosten H. 2006. Nonpollen palynomorphs from modern Alder carrs and their potential for interpreting microfossil data from peat. Rev Palaeobot Palynol 141:7-31.

Pregitzer KS, DeForest JL, Burton AJ, Allen MF, Ruess RW, Hendrick RL. 2002. Fine root architecture of nine North American trees. Ecol Monogr 72:293.

Pregitzer KS, Kubiske ME, Yu CK, Hendrick RL. 1997. Relationships among root branch order, carbon, and nitrogen in four temperate species. Oecologia 111:302-8.

Pretzsch H. 2009. Forest dynamics, growth, and yield. Berlin: Springer. pp 1-39.

Rahmstorf S, Coumou D. 2011. Increase of extreme events in a warming world. Proc Natl Acad Sci 108:17905-9. https://ww w.pnas.org/content/108/44/17905.short.

Schröder P. 1989. Aeration of the root system in Alnus glutinosa L. Gaertn. Annales des Sciences Forestières 46:310s-4s.

Schuldt B, Buras A, Arend M, Vitasse Y, Beierkuhnlein C, Damm A, Gharun M, Grams TEE, Hauck M, Hajek P, Hartmann H, Hiltbrunner E, Hoch G, Holloway-Phillips M, Körner C, Larysch E, Lübbe T, Nelson DB, Rammig A, Rigling A, Rose L,
Ruehr NK, Schumann K, Weiser F, Werner C, Wohlgemuth T, Zang CS, Kahmen A. 2020. A first assessment of the impact of the extreme 2018 summer drought on Central European forests. Basic Appl Ecol 45:86-103.

Stott P. 2016. Climate change. How climate change affects extreme weather events. Science 352:1517-8. https://science.sc iencemag.org/content/352/6293/1517.short?casa_token=e8xj o5mco7gaaaaa:t6xtz95mveateq4cy4ikdoo5ejkqwsmiodfliws 1 tefilrklppiyj00bngsrxjvfistqusp2kst2jw.

Succow M, Joosten H. 2001. Moorkunde. Stuttgart: E. Schweizerbart'sche Verlagsbuchhandlung.

Swanston CW, Myrold DD. 1997. Incorporation of nitrogen from decomposing red alder leaves into plants and soil of a recent clearcut in Oregon. Can J For Res 27:1496-502.

Tanneberger F, Tegetmeyer C, Busse S, Barthelmes A. 2017. The peatland map of Europe. Mires Peat 19:1-17.

Thormann MN, Bayley SE. 1997. Decomposition along A moderate-rich fen-marsh peatland gradient in boreal Alberta, Canada. Wetlands 17:123-37.

Tuittila E-S, Komulainen V-M, Vasander H, Laine J. 1999. Restored cut-away peatland as a sink for atmospheric CO 2 . Oecologia 120:563-74.

Voesenek LACJ, Colmer TD, Pierik R, Millenaar FF, Peeters AJM. 2006. How plants cope with complete submergence. New Phytol 170:213-26.

Wang H, Richardson CJ, Ho M. 2015. Dual controls on carbon loss during drought in peatlands. Nat Clim Change 5:584-7.

Wickham H. 2016. ggplot2. Elegant graphics for data analysis. Cham: Springer.

Wieder RK, Lang GE. 1982. A critique of the analytical methods used in examining decomposition data obtained from litter bags. Ecology 63:1636-42.

Wieder RK, Vitt DH, Benscoter BW. 2006. Peatlands and the boreal forest. In: Wieder RK, Vitt DH, Eds. Boreal peatland ecosystems. Berlin: Springer. p 1-8.

World Meteorological Organization (WMO). 2018. WMO statement on the state of the global climate in 2017. Geneva $(\mathrm{CH})$ : WMO (WMO-No. 1212).

Zhang D, Hui D, Luo Y, Zhou G. 2008. Rates of litter decomposition in terrestrial ecosystems: global patterns and controlling factors. J Plant Ecol 1:85-93. 